\title{
A new species of Micropterix Hübner, 1825 from the Orobian Alps (Italy) (Lepidoptera, Micropterigidae)
}

\author{
Hans Christof Zeller ${ }^{1}$, Peter Huemer ${ }^{2}$ \\ 1 Forsthubfeld 14,A-5303 Thalgau,Austria; christof.zeller@gmx.net \\ 2 Tiroler Landesmuseen Betriebsges. m.b.H., Naturwissenschaftliche Sammlungen, Feldstraße 11a, 6020 Innsbruck; \\ p.huemer@tiroler-landesmuseen.at.
}

http://zoobank.org/4D0DEFC4-83DC-4309-8D65-1529E71BDEFB

Received 8 April 2015; accepted 18 August 2015; published: 22 October 2015

Subject Editor: Lauri Kaila.

\begin{abstract}
Micropterix gaudiella Zeller \& Huemer, sp. n. is described from the southern part of the Orobian Alps (Piedmont, Italy) and compared with its likely closest relatives Micropterix isobasella Staudinger, 1871 and Micropterix stuebneri Zeller, Werno \& Kurz, 2013. The new species is well characterized by its wing pattern and colour and by structures of the male genitalia. The species status is furthermore supported by molecular data of the DNA barcode region. The distance to its nearest neighbour Micropterix schaefferi Heath, 1975 is 2.65\%. M. gaudiella is the seventh species of the genus Micropterix Hübner, 1825 probably endemic to the Alps.
\end{abstract}

\section{Introduction}

The European fauna of Micropterigidae has recently gained increasing attention, reflected by faunistic reviews and several taxonomic papers (Corley 2007; Zeller-Lukashort et al. 2007; Thierry and Nel 2012; Zeller-Lukashort et al. 2013). The actual species inventory now seems well advanced as new species are rarely found and usually originate from insufficiently explored Mediterranean countries, with only two remarkable exceptions from the Central European Alps within the last four decades (Heath and Kaltenbach 1984; Kurz et al. 2004). Sampling of an unidentified Micropterix in the Italian Alps (Pizzo Arero, Orobian Alps, Piedmont, Italy) by PH and colleagues in June and July 2013 and 2014 thus came as a surprise. Although only few females were available in first hand, phenotypic appearance and the DNA barcode did not match any hitherto described species from the region. It was therefore decided to search for additional samples and we finally succeeded in collecting a large series of the species in summer 2014 including the male sex. Subsequent analysis of male genitalic characters supported the recognition of a new species, which is described here. 


\section{Material and methods}

Our study is based on almost 277 specimens of the new Micropterix species and uncounted material of all European congeners. The type material is only partially set whereas several samples were only spread and dried immediately after collecting to ensure sufficient quality of DNA samples. Genitalia preparations followed standard techniques used for the family Micropterigidae (Zeller-Lukashort et al. 2007). Photographs of the adults were taken with an Olympus SZX 10 binocular microscope and an Olympus E-3 digital camera and developed using the software HELICON FOCUS 4.3, ADOBE PHOTOSHOP CS4 and LIGHTROOM 2.3. DNA barcode sequences are based on a 658 base-pair long segment of the mitochondrial COI gene (cytochrome c oxidase 1). DNA samples (dried legs) were prepared according to the prescribed standards (deWaard et al. 2008). Present authors and associated colleagues tried to obtain DNA barcodes of the majority of European Micropterigidae. Legs from 379 specimens belonging to 57 species of Micropterix have so far been processed at the Canadian Centre for DNA Barcoding (CCDB, Biodiversity Institute of Ontario, University of Guelph) to obtain DNA barcodes (BOLD 2015) using the standard high-throughput protocol described in Ivanova et al. (2006) and deWaard et al. (2008). DNA sequencing resulted in a barcode fragment of $658 \mathrm{bp}$ for a total of 149 specimens and 29 species (BOLD 2015), partially published earlier by Lees et al. (2010). Ninety-one sequences belonging to 25 species are treated in this study and enable delimitation of the new species. Details of successfully sequenced voucher specimens including complete voucher data and images can be accessed in the Barcode of Life Data Systems: public dataset "Lepidoptera of the Alps - Micropterix [DS-LEALMIC]" (BOLD 2015; Ratnasingham and Hebert 2007). Degrees of intra- and interspecific variation in the DNA barcode fragment were calculated under Kimura 2-parameter (K2P) model of nucleotide substitution using analytical tools in BOLD Systems v3.0 (BOLD 2015). A neighbour-joining tree of DNA barcode data of European taxa was constructed using MEGA 5 (Tamura et al. 2011) under the K2P model for nucleotide substitutions.

The morphology of the new species is compared with similar species from the Alps and also from other regions of Europe (Kurz and Kurz 2015). We consequently build on the important identification treatments by Heath (1987), Kozlov (1989, 1990a, b) and Zeller-Lukashort et al. (2007). For more information about collection sites, preparation techniques and data archive of Micropterix spp. see Zeller-Lukashort et al. (2007).

Abbreviations of private and institutional collections:

$\begin{array}{ll}\text { MBCG } & \text { Italy, Bergamo, Museo di Scienze Naturali "Enrico Caffi”; } \\ \text { RCTM } & \text { Research Collection Toni Mayr, Feldkirch, Austria; } \\ \text { RCCZ } & \text { Research Collection Christof Zeller, Thalgau, Austria; } \\ \text { RCNP } & \text { Research Collection Norbert Pöll, Bad Ischl, Austria; } \\ \text { RCSO } & \text { Research Collection Siegfried Ortner, Bad Ischl, Austria; } \\ \text { TLMF } & \text { Tiroler Landesmuseum Ferdinandeum, Innsbruck, Austria. }\end{array}$

\section{Results}

\section{Checklist of European Micropterix}

The species listed below occur within Europe (Karsholt 2015, Kurz and Kurz 2015), presented in an order considered to reflect morphological relationships among the species as suggested by Kurz 
et al. (2015). Many of the morphological characters of Micropterix have been found to be more or less similar in smaller or greater groups of species and it has been assumed that similarities or synapomorphies of the male genitalia indicate a closer relationship. Based on a specific character matrix several characters have been selected and attributed as plesiomorphic or apomorphic (but see Kurz et al. 2015).

Micropterix mansuetella Zeller, 1844

Micropterix amsella Heath, 1975

Micropterix calthella (Linnaeus, 1761)

Micropterix isobasella Staudinger, 1871

Micropterix stuebneri Zeller, Werno \& Kurz, 2013

Micropterix gaudiella sp. $\mathrm{n}$.

Micropterix granatensis Heath, 1981

Micropterix aglaella (Duponchel, 1838)

Micropterix wockei Staudinger, 1870

Micropterix aureatella (Scopoli, 1763)

Micropterix herminiella Corley, 2007

Micropterix aruncella (Scopoli, 1763)

Micropterix corcyrella Walsingham, 1919

Micropterix lakoniensis Heath, 1985

Micropterix kardamylensis Rebel, 1903

Micropterix igaloensis Amsel, 1951

Micropterix cassinella Kurz, Kurz \& Zeller, 2010

Micropterix klimeschi Heath, 1973

Micropterix completella Staudinger, 1871

Micropterix tunbergella (Fabricius, 1787)

Micropterix sicanella Zeller, 1847

Micropterix cypriensis Heath, 1985

Micropterix aureoviridella (Höfner, 1898)

Micropterix maschukella Alphéraky, 1876

Micropterix facetella Zeller, 1850

Micropterix jeanneli Viette, 1949

Micropterix renatae Kurz, Kurz \& Zeller-Lukashort, 1997

Micropterix minimella Heath, 1973

Micropterix italica Heath, 1981

Micropterix erctella Walsingham, 1919

Micropterix uxoria Walsingham, 1919

Micropterix paykullella (Fabricius, 1794)

Micropterix garganoensis Heath, 1960

Micropterix imperfectella Staudinger, 1859

Micropterix tuscaniensis Heath, 1960

Micropterix hartigi Heath, 1981

Micropterix allionella (Fabricius, 1794)

Micropterix trifasciella Heath, 1965 
Micropterix rothenbachii Frey, 1856

Micropterix huemeri Kurz, Kurz \& Zeller-Lukashort, 2004

Micropterix ibericella Caradja, 1920

Micropterix zangheriella Heath, 1963

Micropterix schaefferi Heath, 1975

Micropterix emiliensis Viette, 1950

Micropterix osthelderi Heath, 1975

Micropterix trinakriella Kurz, Zeller-Lukashort \& Kurz, 1997

Micropterix vulturensis Heath, 1981

Micropterix rablensis Zeller, 1868

Micropterix myrtetella Zeller, 1850

Micropterix croatica Heath \& Kaltenbach, 1984

Micropterix fenestrellensis Heath \& Kaltenbach, 1984

\section{Taxonomic part}

\section{Micropterix gaudiella Zeller \& Huemer, sp. n.}

http://zoobank.org/4AA658ED-DED7-46A7-908E-231CBC52A8A7

Material. Holotype ỡ: Italia sept., Bergamo, Alpi Orobie Rifugio Ca d'Arera 1600 m 947,8’'E, 4555,07’N 25.vi.2014, leg. Huemer TLMF 2014-006 (TLMF), label with identification numbers CZ-Z30577, label "DNA BARCODE TLMF Lep14851" and red label "HOLOTYPE of Micropterix gaudiella Zeller \& Huemer". - Paratypes: 4 , same locality as holotype, but 16.vii.2013, leg. Massaro M. (MBCG), labels with identification numbers CZ-Z30771, CZ-Z30774-CZZ30776; 3 đ, 2ᄋ, same locality as holotype, but 17.vii.2014, leg. Siegfried Ortner (RCSO), labels with identification numbers CZ-Z29417, CZ-Z29459-CZ-Z29462; 40 đ̊, 22 ㅇ, same data as holotype, but leg. Norbert Pöll (RCNP), labels with identification numbers CZ-Z29463-CZ-Z29524; 69 ô, 26 ㅇ, same data as holotype, but leg. Mayr Toni (RCTM), labels with identification numbers CZ-Z29360-CZ-Z29369, CZ-Z29371-CZ-Z29416, CZ-Z29418-CZ-Z29445, CZ-Z29446 and AP: MK-1072, CZ-Z29448-CZ-Z29457; 76 , 15 ㅇ, same data as holotype (TLMF), labels with identification numbers CZ-Z29330-CZ-Z29347, CZ-Z30561-CZ-Z30576, CZ-Z30578-CZ-Z30580, CZ-Z30582-CZ-Z30623, CZ-Z30625-CZZ30631, CZ-Z30633-CZ-Z30634, CZ-Z30636-CZ-Z30638; 16 §̊, same locality as holotype, but 23.vi.2014, labels with identification numbers CZ-Z29314-CZ-Z29327, CZ-Z29328 and AP-Nr 1/2014, CZ-Z29329; 1 ô, same data as holotype (TMLF), label with identification number CZ-Z30581, label "DNA BARCODING TMLF Lep14853"; 1 , , same data as holotype (TMLF), label with identification number CZ-Z30624, label "DNA BARCODING TMLF Lep14852"; 1 + , same locality as holotype, but 25.vi.2013, leg. Huemer (TLMF), label with identification number CZ-Z29359, label "DNA BARCODING TMLF Lep09987". All 276 paratypes bear red label "PARATYPE of Micropterix gaudiella Zeller \& Huemer".

Description. Adult (Figs 1, 2). Forewing length 3.5-3.9 mm (ठ, n=206), 4.0-4.4 mm ( Head black-brown; vestiture of hair-like scales on the head, yellow to dirty yellow; antennae dark brown, respectively $3 / 4(\lesssim)$ and $1 / 2$ ( $($ ) of forewing length; thorax and tegulae violet with golden reflection; forewing dull bluish with conspicuously broad and mostly bronzy golden markings: a trapeziform fascia at $1 / 4$, at $1 / 2$ a moderately broad straight fascia across the whole wing width, inwardly oblique, at 3/4 a broad, variably shaped, inwardly convex fascia; fringe bronzy golden, basally bluish violet; hindwing bronzy golden, apically tinged purplish; fringe bronzy golden; legs and abdomen brown, golden shining. 


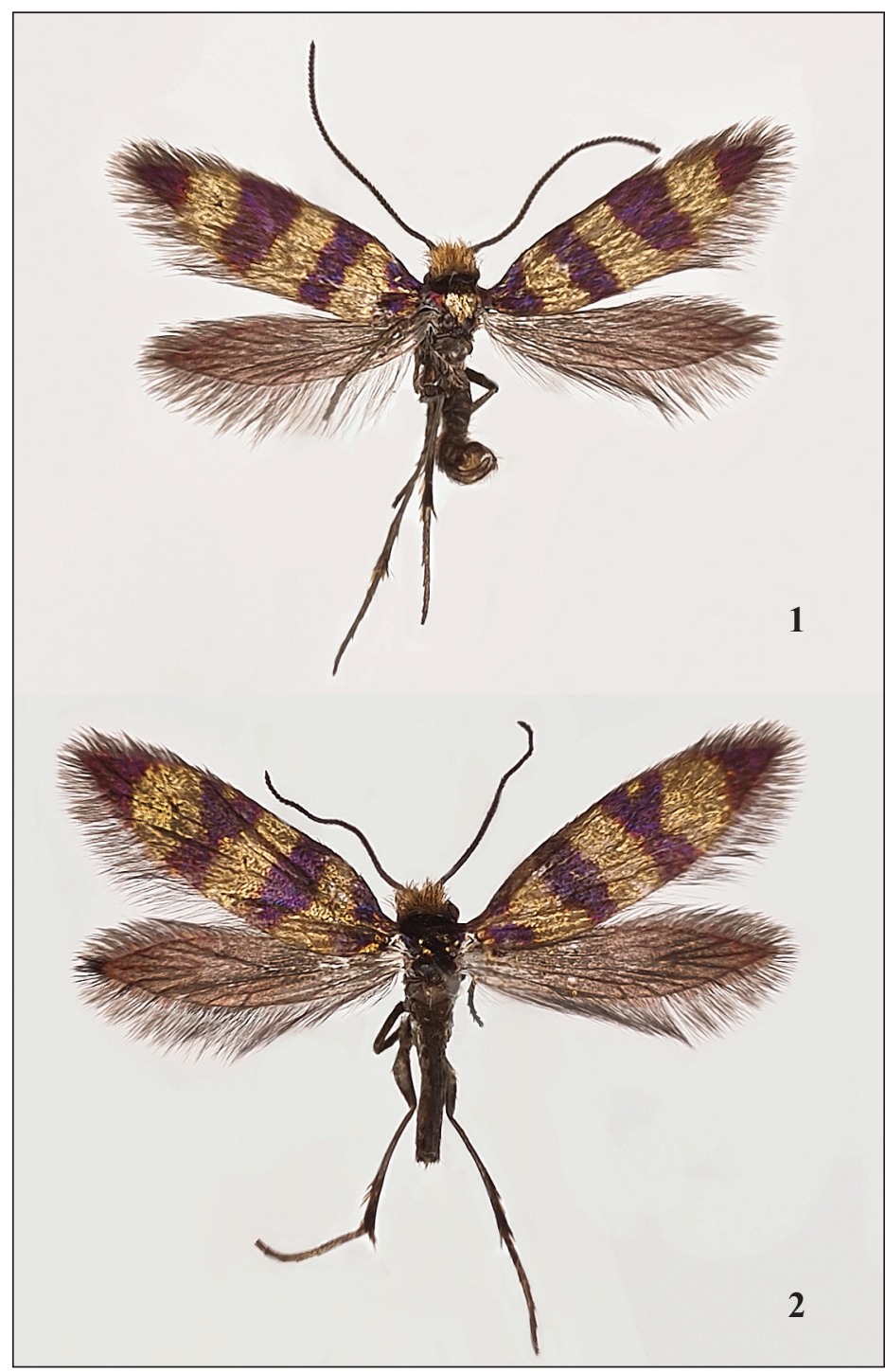

Figures 1-2: Adults of M. gaudiella sp. n. 1: $ð$. 2:

There is some variation in the ground coloration from dull bluish to purple-violet. Sometimes there is also a small spot on the costa at $3 / 5$. The wing pattern differs between the sexes only a little in the broadness of the fasciae, as is typical for the genus.

o Genitalia (Fig. 3). Uncus long, slender, with a broad rounded tip; a paired association of hairlike setae ventrally beyond the uncus; accessory claspers moderately long, nearly keel-shaped; along distal margin, a row of about 10-12 moderately long distally hook-like modified thickened setae oriented in slightly ventral direction; at inner surface proximally another irregular row of five or six shorter, finer setae; valvae moderately long, stout, distal third enlarged and strongly bent dorsally, constricted at the point of inflection; on the inner surface of the valvae a group of shorter 


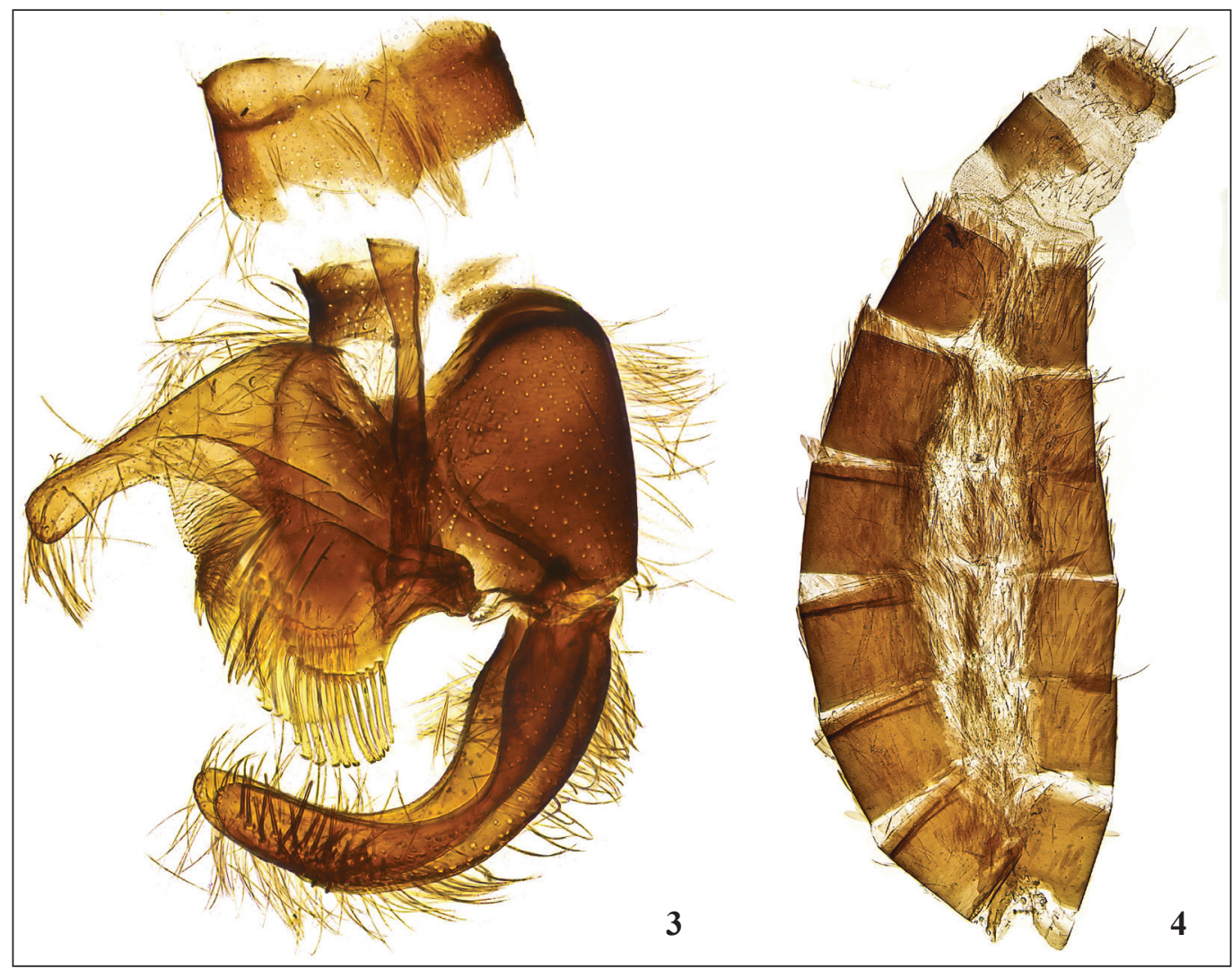

Figures 3-4: Genitalia of M. gaudiella sp. n.. 3: ふึ. 4. ㅇ.

setae postbasally; on the inner surface of the lower margin two to three irregular rows of shorter spinous setae and some longer setae on the distal fourth part.

q Genitalia (Fig. 4). Tergite IX missing; sternite IX reduced, constricted medially, with strongly fringed lateral margins, without diagnostic features. Terminal papillae with two sclerotized plates forming an undiagnostic band; receptaculum seminis long and slender, constricted in the first third, with transverse striation typical for the genus.

Diagnosis. M. trifasciella from Piedmont (Italy) shows somewhat similar but conspicuously narrower fasciae and differs in the ground colour. M. rablensis from Friuli (Italy), Carinthia (Austria) and western Slovenia shows a somewhat similar wing pattern but is predominantly smaller and differs in the reddish bronzy golden to purple ground coloration of the forewings. M. completella, endemic to Sardinia and Corsica (Thierry and Nel 2012), has usually lighter purple-violet forewings with comparably broad fasciae and differs in the shape of the outer fascia. From all these mentioned species, the new species is furthermore clearly separated by its male genitalia, e.g. by the distinct shape of uncus and accessory claspers as well as by the orientation and form of the 10-12 long setae on the accessory claspers (Kurz and Kurz 2015). In the male genitalia, the new species closely resembles M. isobasella from Valais (Switzerland) (Fig. 5) and the recently described M. stuebneri from Sierra Nevada (Spain), being distinguished from M. isobasella mainly 


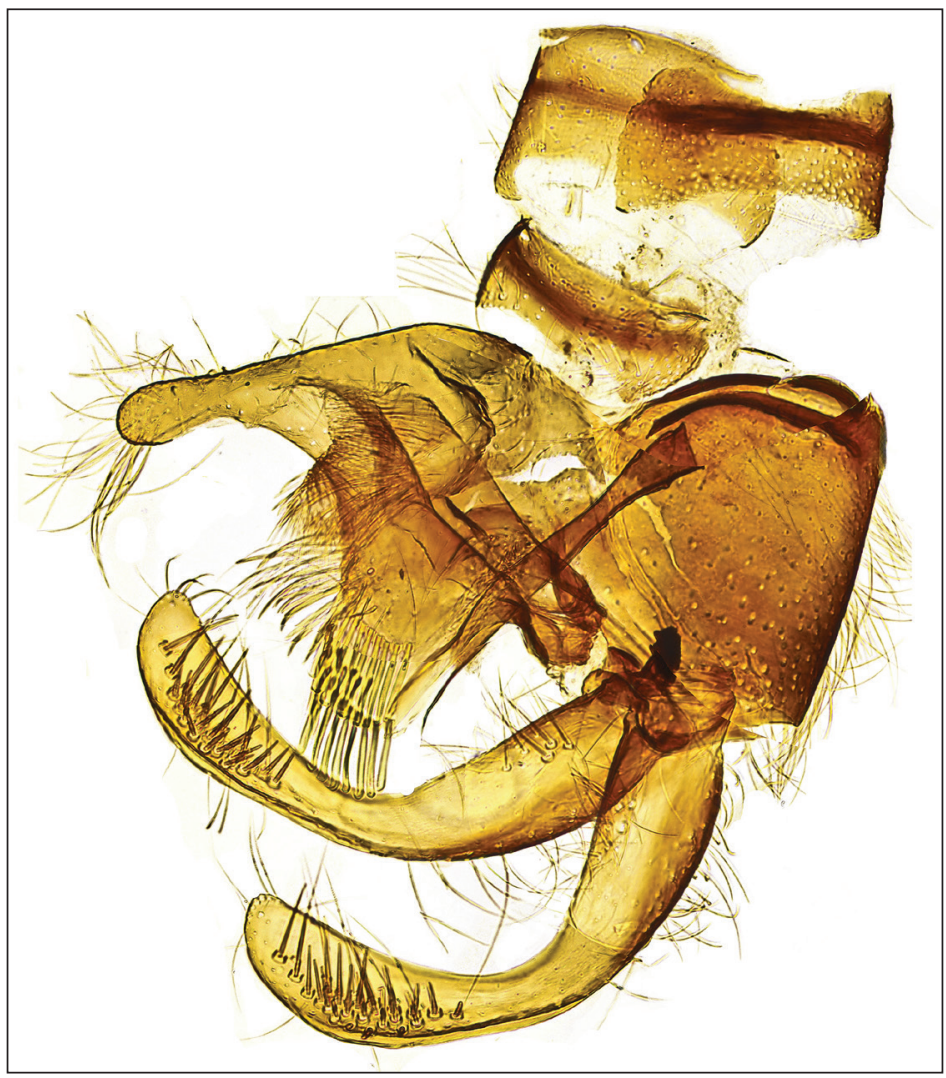

Figure 5. Male genitalia of M. isobasella.

by its longer uncus and the partly hook-like modified thickened setae at the rounded distal margin of the accessory claspers and from M. stuebneri mainly by its distinctly shorter and smaller accessory claspers (Zeller-Lukashort et al. 2013). M. isobasella can also easily be distinguished by its unicolorous golden forewings without any significant markings. In the female genitalia the new species differs from $M$. rablensis by the shape of sternite IX, from M. trifasciella and M. completella by its strongly fringed lateral margins of sternite IX. There are no differences in the female genitalia between $M$. isobasella and the new species.

Based on morphological characters (Kurz et al. 2015), the new species is considered to belong to a species-complex together with $M$. calthella, M. isobasella and the recently described M. stuebneri.

Molecular data. The intraspecific divergence of the barcode region of M. gaudiella $\mathrm{sp}$. $\mathrm{n}$. is moderate with a mean distance of $0.46 \%$ and a maximum distance of $0.77 \%(n=4)$ (Tab. 1). The minimum distance to the nearest neighbour M. schaefferi on the contrary is much higher with $2.65 \%$ (mean dist. $3.18 \%$, max. dist. $3.76 \% ; n=9$ ). The minimum distance to the morphologically closest $M$. isobasella is $3.67 \%$ (mean dist. $3.85 \%$, max. dist. $4.18 \%$; $n=1$ ) and to $M$. stuebneri 4.73\% (mean dist. $4.99 \%$, max. dist. 5.22\%; $n=1$ ).

Distribution. The new species is only known from the mountain Pizzo Arero (Alpi Orobie, Piedmont, Italy) from an elevation of about $1600 \mathrm{~m}$. 
Table 1. Intraspecific distance and interspecific divergence to the nearest neighbour in the genus Micropterix, based on 25 European species. Source: DNA Barcode data from BOLD (Barcode of Life Database, cf. Ratnasingham and Hebert 2007).

\begin{tabular}{|c|c|c|c|c|c|}
\hline Species & $\begin{array}{l}\text { Mean } \\
\text { Intra }\end{array}$ & Max intra & Nearest neighbour & Nearest species & Distance NN \\
\hline Micropterix allionella & 0.18 & 0.46 & LEATE038-13 & Micropterix rothenbachii & 1.86 \\
\hline Micropterix amsella & N/A & N/A & LEFIG229-10 & Micropterix mansuetella & 5.35 \\
\hline Micropterix aruncella & 1.7 & 2.99 & PHLAG682-12 & Micropterix schaefferi & 2.97 \\
\hline Micropterix aureatella & 0.39 & 0.77 & PHLAG682-12 & Micropterix schaefferi & 2.74 \\
\hline Micropterix aureoviridella & 0.21 & 0.46 & PHLAG682-12 & Micropterix schaefferi & 2.74 \\
\hline Micropterix calthella & 0.18 & 0.46 & PHLAG682-12 & Micropterix schaefferi & 2.74 \\
\hline Micropterix erctella & N/A & N/A & PHLAG682-12 & Micropterix schaefferi & 2.05 \\
\hline Micropterix facetella & 1.84 & 1.84 & PHLAG682-12 & Micropterix schaefferi & 2.51 \\
\hline Micropterix gaudiella & 0.46 & 0.77 & PHLAD506-11 & Micropterix schaefferi & 2.65 \\
\hline Micropterix hartigi & N/A & N/A & PHLAG682-12 & Micropterix schaefferi & 2.74 \\
\hline Micropterix igaloensis & N/A & N/A & LEATE039-13 & Micropterix schaefferi & 2.9 \\
\hline Micropterix isobasella & N/A & N/A & PHLAG682-12 & Micropterix schaefferi & 3.01 \\
\hline Micropterix jeanneli & N/A & N/A & PHLAG682-12 & Micropterix schaefferi & 4.15 \\
\hline Micropterix klimeschi & N/A & N/A & PHLAE527-11 & Micropterix aruncella & 3.79 \\
\hline Micropterix mansuetella & N/A & N/A & LTOLB478-09 & Micropterix calthella & 4.35 \\
\hline Micropterix myrtetella & N/A & $\mathrm{N} / \mathrm{A}$ & PHLAG682-12 & Micropterix schaefferi & 1.82 \\
\hline Micropterix osthelderi & 0 & 0 & PHLAG682-12 & Micropterix schaefferi & 3.21 \\
\hline Micropterix rablensis & N/A & N/A & PHLAG682-12 & Micropterix schaefferi & 2.62 \\
\hline Micropterix rothenbachii & 0.21 & 0.32 & PHLAG787-12 & Micropterix allionella & 1.86 \\
\hline Micropterix schaefferi & 0.41 & 1.12 & MICOW166-09 & Micropterix vulturensis & 0.9 \\
\hline Micropterix sicanella & N/A & $\mathrm{N} / \mathrm{A}$ & PHLAG682-12 & Micropterix schaefferi & 3.44 \\
\hline Micropterix stuebneri & N/A & N/A & PHLAG682-12 & Micropterix schaefferi & 2.28 \\
\hline Micropterix tunbergella & 0.05 & 0.16 & PHLAG682-12 & Micropterix schaefferi & 3.45 \\
\hline Micropterix vulturensis & N/A & N/A & PHLAG682-12 & Micropterix schaefferi & 0.9 \\
\hline Micropterix wockei & N/A & N/A & LEATE039-13 & Micropterix schaefferi & 3.89 \\
\hline
\end{tabular}

Life history. The early stages are unknown. The new species was observed from the end of June to mid-July near the border of a montane-subalpine beech forest with tall herbaceous vegetation and bushes (Figs 6, 7), congregating on Rosa sp. feeding on its pollen. Together with the new species, M. aruncella (Scopoli, 1763) was recognized on flowers of Rosa sp. too (Fig. 8). At the same locality $M$. rothenbachii Frey, 1856 was also found. Several specimens of the new species were swept from flowers of Helianthemum spp. in adjacent subalpine grassland. The habitat is southern exposed slopes on limestone.

Etymology. It was a great pleasure to find this unexpected new species from the Italian Alps. Therefore the new species is called "gaudiella", derived from the Latin word "gaudium", which means "fun, pleasure, happiness".

Remark. The labels used by PH, Melania Massaro, Toni Mayr, Norbert Pöll and Siegfried Ortner differ in the usage of local names of the type locality but all refer to the same spot centred on $9^{\circ} 47,8^{\prime} \mathrm{E} ; 4^{\circ} 55,07^{\prime} \mathrm{N}$ (DDM). According to Melania Massaro there are additional specimens collected at the type locality and deposited in MBCG, which are not examined and therefore not included in the type series. 


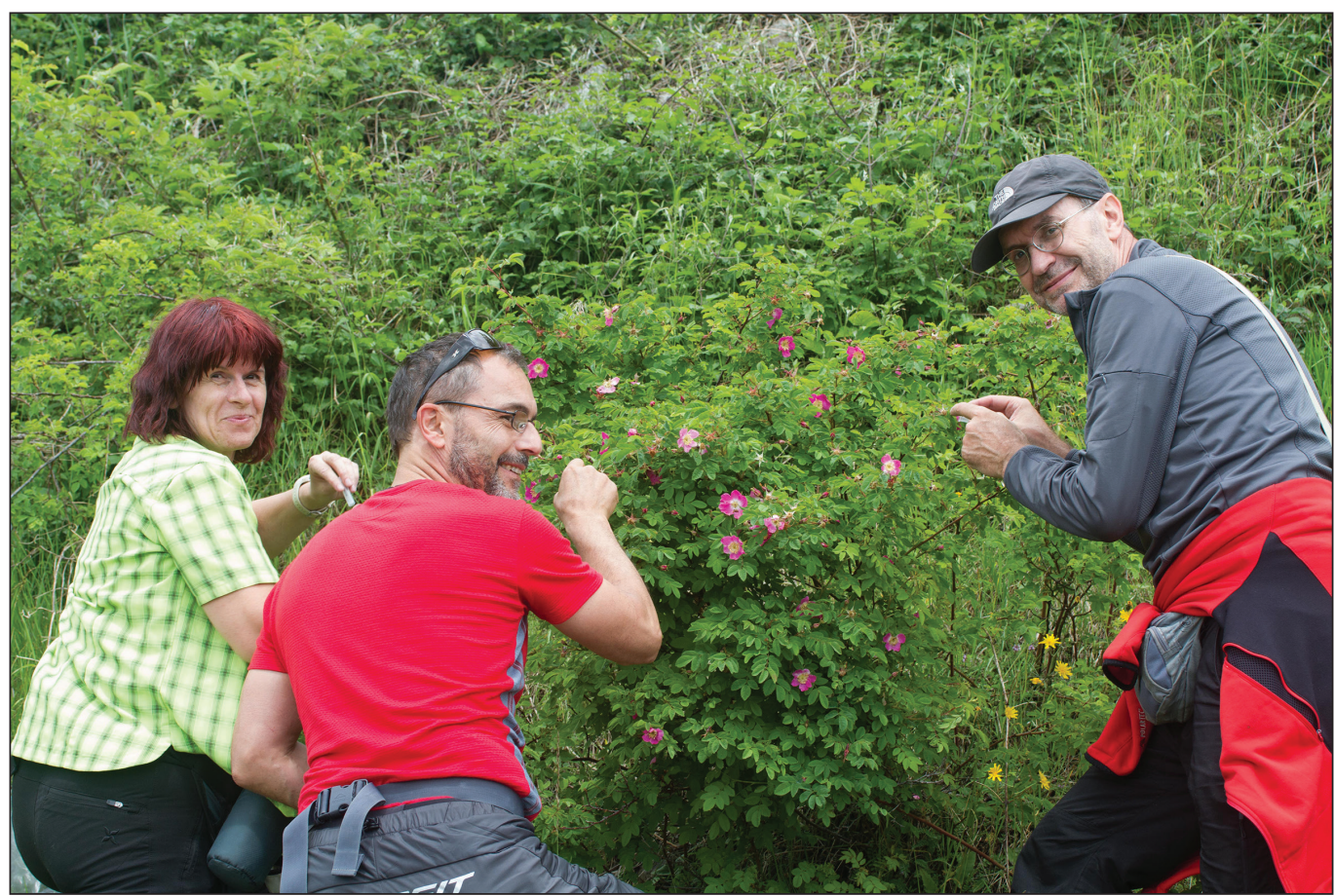

Figure 6. Biotope of M. gaudiella and the lucky collectors Marlies Mayr, Toni Mayr and Norbert Pöll.

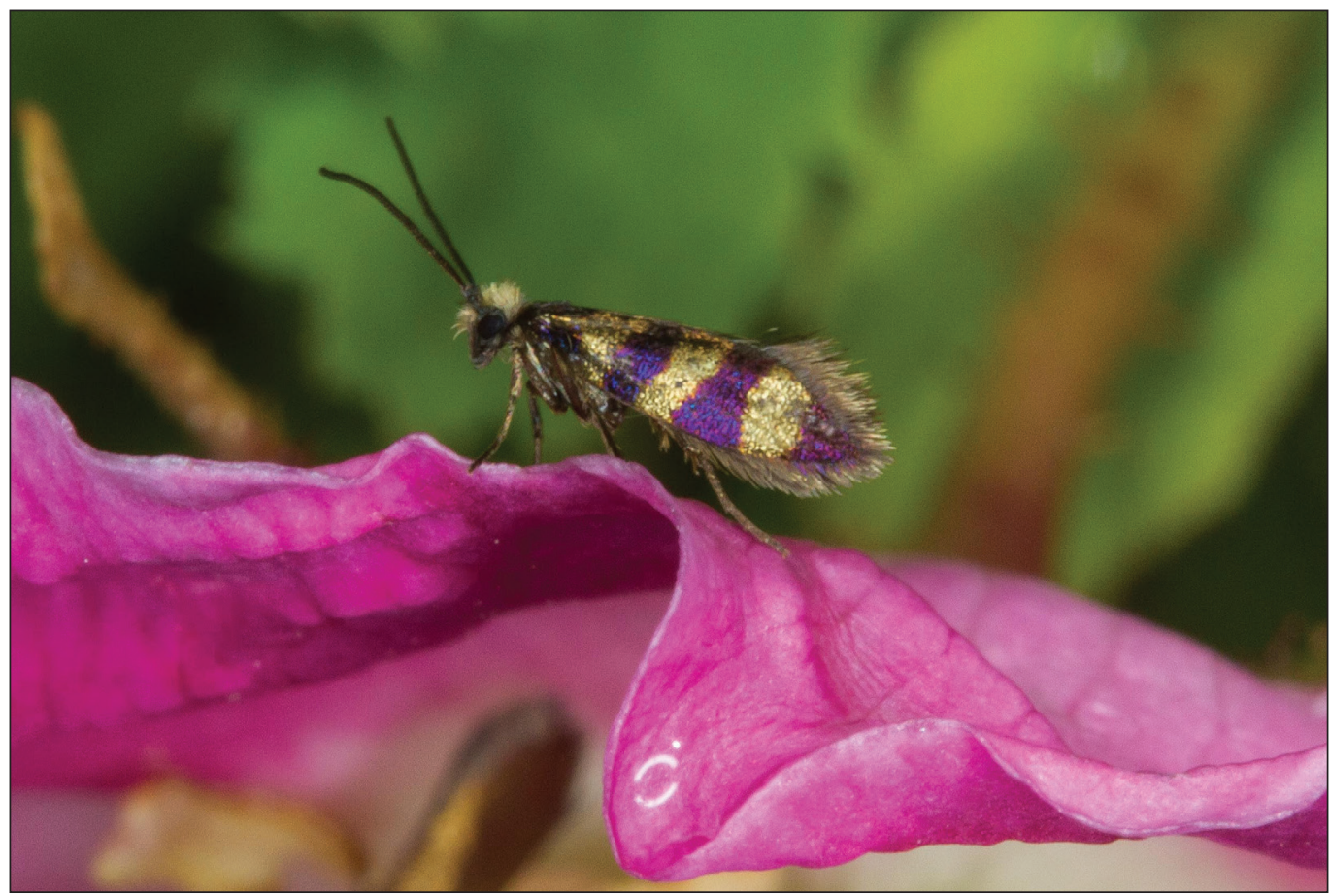

Figure 7. M. gaudiella sp. n., resting on a flower of Rosa sp.. 


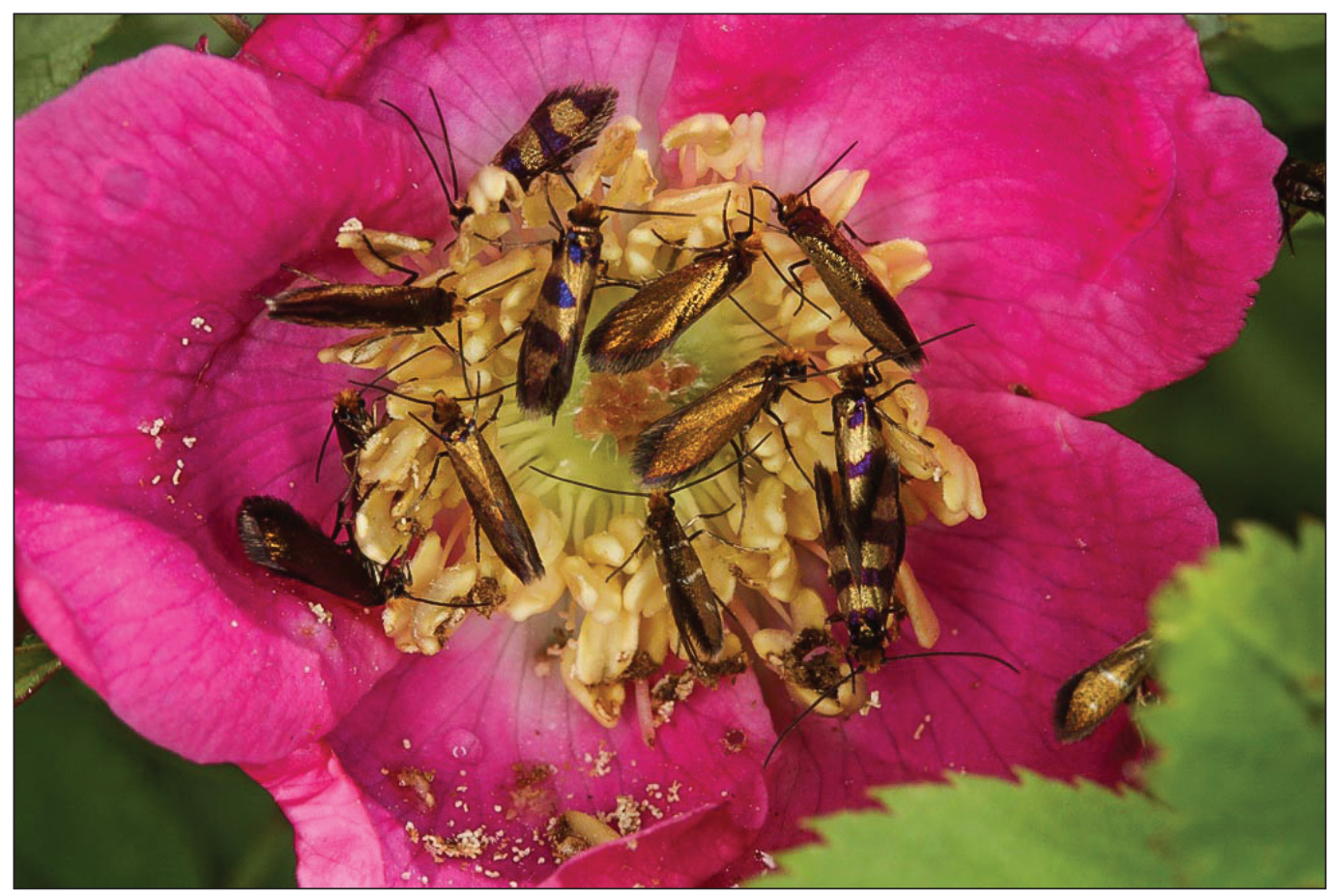

Figure 8. M. aruncella and M. gaudiella sp. n. feeding on Rosa sp.

\section{Molecular analysis}

Sequencing of European species of Micropterix resulted in barcode fragments for 61 specimens, plus 30 unpublished or public records from external projects (e.g. Barcoding Fauna Bavarica and Finnish Barcode of Life), covering altogether 25 species, supplementing data of extra-European species that have been published by Lees et al. (2010). 74 full barcode sequences of $658 \mathrm{bp}, 13$ sequences longer than $600 \mathrm{bp}$ and four sequences of ca. $400 \mathrm{bp}$ were included in the analysis. The smaller fragments were single sequence only (M. amsella, M. mansuetella, and M. rablensis).

Barcode variation is insufficiently known for a considerable portion of species due to lack of successfully sequenced samples (Table 1). Intraspecific distance is low and ranges from $0 \%$ to $2.99 \%$ (mean $0.92 \%$ ) but may include cases of overlooked cryptic diversity in species with high divergence (i.e. $M$. aruncella, $M$. facetella). Interspecific divergence for the whole sample is moderately high with mean divergence of $4.77 \%$ and maximum of $8.91 \%$, and a mean and maximum distance to the nearest neighbour of $2.84 \%$ and $5.35 \%$ respectively. The divergence is $<1 \%$ only in one species pair (M. schaefferi and M. vulturensis) (Table 1, Fig. 9).

\section{Discussion}

Alpha-taxonomy of European Micropterix seems quite well established with relatively few taxa described during the last decades, so it is striking to find a new species in Central Europe. By contrast, the distribution of the majority of Micropterix species is only moderately well documented with few 


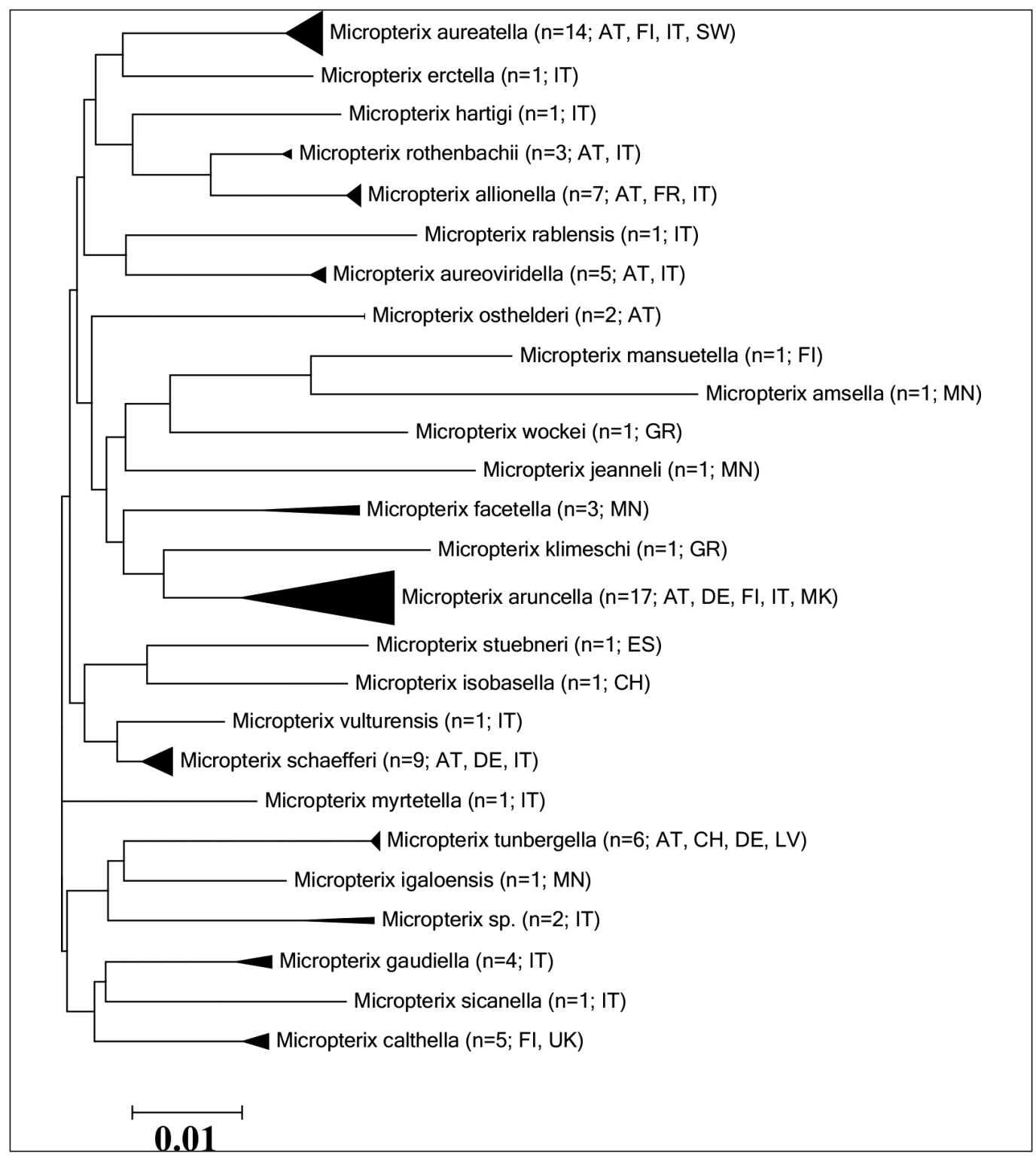

Figure 9. Neighbour-joining tree (Kimura 2-parameter, built with MEGA 5; cf. Tamura et al. 2011). Note: the scale bar only applies to internal branches between species. The width of the triangles represents the sample size, and the depth the relative genetic variation within the cluster $(2 \times$ scale bar). Source: DNA Barcode data from BOLD (Barcode of Life Database, cf. Ratnasingham and Hebert 2007).

faunistic studies, particularly as concerns the Mediterranean region. Despite this shortcoming, it already appears evident from published sources that Micropterix exhibits remarkable levels of narrow range endemicity. Indeed about three-quarters of the European taxa can be clustered into the following disjunct endemism groups (Karsholt 2015; Zeller-Lukashort et al. 2013; Kurz and Kurz 2015). 
Apennines: 9 out of 20 species are endemic.

Alps: 7 out of 19 species are endemic.

Balkan Peninsula: 9 out of 17 species are endemic.

Iberian Peninsula: 5 out of 8 species are endemic.

Mediterranean islands: 8 species are endemic.

Black Sea area: 1 species is endemic.

Also, only 12 species (about one-quarter of European Micropterix) are widely distributed across Europe, and only one species (M. aureatella) reaches Japan (Kurz and Kurz 2015). M. aruncella, M. aureatella, M. calthella, $M$. mansuetella and $M$. tunbergella are known to range across from the mainland to geographically well separated islands (although a few micropterigids occur within an island group, such as Sabatinca occurring in both North and South Island of New Zealand: Gibbs 1983; Gibbs and Lees 2014; see also Imada et al. 2011). Endemism in the Lepidoptera fauna of the Alps in general and Micropterix in particular probably largely results from the history of glaciation, which is reflected in nine biogeographic zones defined by vegetation (Ozenda 1988). These zones have been partially considered as areas of endemism for Lepidoptera (Huemer, 1988). The majority of endemic Micropterix occur in the Western Alps and are restricted to the so-called "Inner Alps" (i.e. M. isobasella, M. paykullella, M. trifasciella and M. fenestrellensis) whereas M. huemeri is restricted to the adjacent "Pre-Ligurian" biogeographic zone. However, the highest diversity of endemic Lepidoptera in general is present in the so-called "Gardesan-Illyrian zone" of the south-eastern Alps which is defined by limestone massifs at the southern border of the Alps reaching from Lake Como in the west to the Karawanks in the east. More than 30 endemic Lepidoptera species are known from this area (Huemer 1998). M. gaudiella is the first species of the genus Micropterix probably endemic to this zone, while a further species, $M$. rablensis, is more widespread and also occurs in the northern part of the Eastern Alps. The Orobian Alps in particular seem to have attracted insufficient attention among lepidopterists so far and still host a considerable number of cryptic species belonging to various groups. A new species of Kessleria (Huemer \& Mutanen, 2015) and a distinct subspecies of Colostygia (Huemer \& Mayr, 2015) are striking examples. It seems not unlikely that further undescribed endemic Micropterix may be found in other remote and undercollected areas of Europe, e.g. on the Balkan and Iberian Peninsulas. Outside Europe, despite the efforts of John Heath, there are probably a number of undetected species in North Africa, while the Himalayas as far as China are virtually unexplored for the genus (but see Lees et al. 2010).

\section{Acknowledgements}

We are particularly grateful to Paul Hebert and his team at the Canadian Centre for DNA Barcoding (Guelph, Canada), whose sequencing work was enabled by funding from the Government of Canada to Genome Canada through the Ontario Genomics Institute. We are also grateful to the Ontario Ministry of Research and Innovation and to NSERC for their support of the BOLD informatics platform. We are furthermore indebted to the Promotion of Educational Policies, University and Research Department of the Autonomous Province of Bolzano - South Tyrol for helping to fund the project "Genetic biodiversity archive - DNA barcoding of Lepidoptera of the central Alpine region (South, East and North Tyrol)", and to the Austrian Federal Ministry of Science, Research and Economics for funds received in the framework of ABOL (Austrian Barcode of Life). 
Dr. Marko Mutanen (Oulu) and Dr. Andreas Segerer (Munich) kindly gave us access to unpublished barcode sequences. We are furthermore grateful to Toni Mayr, Siegfried Ortner and Norbert Pöll for the loan of their material and provision of useful photos, to Mag. Michael Kurz for help regarding the preparation of the female genitalia. Dr. David Lees (London) and Martin Corley (Faringdon, Oxford) kindly improved our English and gave us useful hints. Stefan Heim (Tiroler Landesmuseen, Innsbruck) kindly developed figures of set adults and genitalia. Finally we acknowledge the kind support received from Dr. Marco Valle, Dr. Paolo Pantini and Dr. Melania Massaro (Museo Civico di Science Naturali “E. Caffi”, Bergamo) during our stay in Italy and supplementing samples of the new species.

\section{References}

BOLD (2015) BOLD: The Barcode of Life Data System (www.barcodinglife.org). http://www.boldsystems.org Corley M (2007) A brief review of the Micropterigidae of Portugal, with description of a new species of $\mathrm{Mi}$ cropterix Hübner. Nota lepidopterologica 30(1): 71-78.

deWaard JR, Ivanova NV, Hajibabaei M, Hebert PDN (2008) Assembling DNA Barcodes: Analytical Protocols. In: Cristofre M (Ed.) Methods in Molecular Biology: Environmental Genetics. Humana Press Inc., Totowa, USA, 275-293. doi: 10.1007/978-1-59745-548-0_15

Heath J, Kaltenbach T (1984) New species of Micropterix Hübner (Lepidoptera: Zeugloptera: Micropterigidae) from Italy and Yugoslavia. Entomologist's Gazette 35: 21-23.

Gibbs GW (1983) Evolution of Micropterigidae (Lepidoptera) in the SW Pacific. GeoJournal 7.6: 505-510. doi: $10.1007 / \mathrm{bf} 00218523$

Gibbs GW, Lees DC (2014) New Caledonia as an evolutionary cradle: a re-appraisal of the jaw-moth genus Sabatinca (Lepidoptera: Micropterigidae) and its significance for assessing the antiquity of the island's fauna. In: Guilbert É, Robillard T, Jourdan H, Grandcolas P (Eds) Zoologia Neocaledonica 8. Biodiversity studies in New Caledonia. Muséum national d'Histoire naturelle, Paris, 239-266. [Mémoires du Muséum national d'Histoire naturelle; 206]

Heath J (1987) A check list of the genus Micropterix Hübner [1825] (Lepidoptera: Zeugloptera, Micropterigidae). Entomologist's Gazette 38: 205-207.

Huemer P (1998) Endemische Schmetterlinge der Alpen - ein Überblick (Lepidoptera). Stapfia 1998(55): 229-256.

Huemer P, Mayr T (2015) Eine neue Unterart von Colostygia kitschelti aus den Bergamasker-Alpen, mit Bemerkungen zum Artkonzept im C. austriacaria-Komplex (Lepidoptera: Geometridae). Wissenschaftliches Jahrbuch der Tiroler Landesmuseen (in press).

Huemer P, Mutanen M (2015) Alpha taxonomy of the genus Kessleria Nowicki, 1864, revisited in times of DNA-barcoding (Lepidoptera, Yponomeutidae). ZooKeys 503: 89-133. doi: 10.3897/zookeys.503.9590

Imada Y, Kawakita A, Kato M (2011) Allopatric distribution and diversification without niche shift in a bryophyte-feeding basal moth lineage (Lepidoptera: Micropterigidae). Proceedings of the Royal Society B 278: 3026-3033. doi: 10.1098/rspb.2011.0134

Ivanova NV, deWaard JR, Hebert PDN (2006) An inexpensive, automation-friendly protocol for recovering high-quality DNA. Molecular Ecology Notes 6: 998-1002.

Kozlov MV (1989) Short review and key for determination of Micropterix Hbn. (Lepidoptera, Micropterigidae) species of Palaearctic. 2. Key for determination (pt. 1). Vestnik zoologii 1989(6): 26-31. [In Russian]

Kozlov MV (1990a) Short review and key for determination of Micropterix Hbn. (Lepidoptera, Micropterigidae) species of Palaearctic. 3. Key for determination (pt. 2). Vestnik zoologii 1990(2): 21-26. [In Russian] 
Kozlov MV (1990b) Short review and key for determination of Micropterix Hbn. (Lepidoptera, Micropterigidae) species of Palaearctic. 4. Results of investigation of the type species. Vestnik zoologii 1990 (3): 28-33. [In Russian]

Karsholt O (2015) Fauna Europaea: Lepidoptera, Micropterigidae. Fauna Europaea version 2.6.2, http:// www.faunaeur.org

Kurz MA, Kurz ME (2015) Naturkundliches Informationssystem. http://www.nkis.info

Kurz MA, Kurz ME, Zeller-Lukashort HC (2004) A new Micropterix species from southern France (Micropterigidae). Nota lepidopterologica 26(3/4): 111-114.

Kurz MA, Kurz ME, Zeller HC (in press) Morphological characters as indicators for a hypothetical arrangement of species in the genus Micropterix Hübner. Mitteilungen der Naturkundlichen Gesellschaft.

Lees DC, Rougerie R, Zeller-Lukashort C, Kristensen NP (2010) DNA mini-barcodes in taxonomic assignment: a morphologically unique new homoneurous moth clade from the Indian Himalayas described in Micropterix (Lepidoptera, Micropterigidae). Zoologica Scripta 39(6): 642-661. doi: 10.1111/j.14636409.2010.00447.x

Ratnasingham S, Hebert PDN (2007) BOLD: The Barcode of Life Data System (http://www.barcodinglife. org). Molecular Ecology Notes 7: 355-364. doi: 10.1111/j.1471-8286.2007.01678.x

Ozenda P (1988) Die Vegetation der Alpen im europäischen Gebirgsraum. Gustav Fischer Verlag, Stuttgart, New York, 353 pp.

Tamura K, Peterson D, Peterson N, Stecher G, Nei M, Kumar S (2011) MEGA5: Molecular Evolutionary Genetics Analysis using Maximum Likelihood, Evolutionary Distance, and Maximum Parsimony Methods. Molecular Biology and Evolution 28: 2731-2739. doi: 10.1093/molbev/msr121

Thierry V, Nel J (2012) Microlépidoptères nouveaux ou peu connus de la faune de France (Lep. Micropterigidae, Blastobasidae, Cosmopterigidae, Gelechiidae). Oreina 20: 17-18.

Zeller-Lukashort HC, Kurz ME, Lees DC, Kurz MA (2007) A review of Micropterix Hübner, 1825 from northern and central Europe (Micropterigidae). Nota lepidopterologica 30(2): 235-298.

Zeller-Lukashort HC, Werno A, Kurz MA (2013) A new species of Micropterix Hübner, [1825] from southern Spain (Lepidoptera: Micropterigidae). SHILAP Revista de Lepidopterologia 41(164): 489-494. 